University of New Orleans

ScholarWorks@UNO

$2-1988$

\title{
Leafcutting and Diet Selection: Relative Influence of Leaf Chemistry and Physical Features
}

Jerome J. Howard

University of New Orleans, jjhoward@uno.edu

Follow this and additional works at: https://scholarworks.uno.edu/biosciences_facpubs

Part of the Biology Commons

\section{Recommended Citation}

Howard, J.J. (1988). Leafcutting ant diet selection: relative influence of leaf chemistry and physical features. Ecology 69 (1): 250-260.

This Article is brought to you for free and open access by the Department of Biological Sciences at ScholarWorks@UNO. It has been accepted for inclusion in Biological Sciences Faculty Publications by an authorized administrator of ScholarWorks@UNO. For more information, please contact scholarworks@uno.edu. 


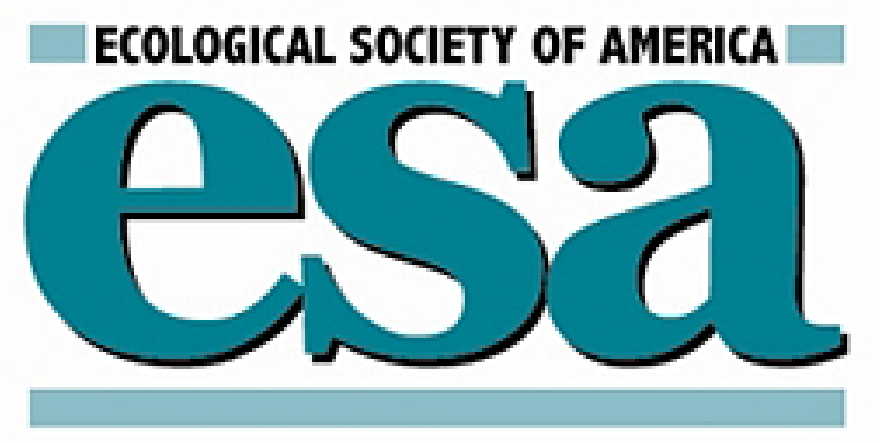

Leafcutting and Diet Selection: Relative Influence of Leaf Chemistry and Physical Features Author(s): Jerome J. Howard

Reviewed work(s):

Source: Ecology, Vol. 69, No. 1 (Feb., 1988), pp. 250-260

Published by: Ecological Society of America

Stable URL: http://www.jstor.org/stable/1943180

Accessed: 08/08/2012 12:33

Your use of the JSTOR archive indicates your acceptance of the Terms \& Conditions of Use, available at http://www.jstor.org/page/info/about/policies/terms.jsp

JSTOR is a not-for-profit service that helps scholars, researchers, and students discover, use, and build upon a wide range of content in a trusted digital archive. We use information technology and tools to increase productivity and facilitate new forms of scholarship. For more information about JSTOR, please contact support@ jstor.org. 


\title{
LEAFCUTTING ANT DIET SELECTION: RELATIVE INFLUENCE OF LEAF CHEMISTRY AND PHYSICAL FEATURES ${ }^{1}$
}

\author{
JEROME J. HOWARD \\ Program in Evolutionary Ecology and Behavior, Department of Biology, \\ University of Iowa, Iowa City, Iowa 52242 USA
}

\begin{abstract}
The effects of leaf toughness, trichome characteristics, nutrient and water availability, and secondary chemistry on diet selection by the leafcutting ant Atta cephalotes were determined using individuals of 49 woody plant species from a tropical deciduous forest in Costa Rica. The palatability of plants was measured by presenting whole leaves to leafcutting ant foragers on trails and counting the number of pieces cut from leaves. The effectiveness of physical barriers to leaf cutting was evaluated by measuring the speed with which ants were able to cut leaves of varying toughness, trichome densities, and trichome lengths.

Plant secondary chemistry was highly correlated with the relative palatability of leaves, while palatability was only marginally correlated with trichome characteristics and plant nutritional quality and was uncorrelated with leaf toughness and water content. Highly palatable leaves generally contained hydrolyzable tannins, while most unpalatable leaves possessed nonpolar extracts found to deter leaf cutting in laboratory bioassays. Within the subset of highly palatable plants, leaf protein content was positively correlated with the number of pieces cut, indicating that secondary chemistry and nutrient availability interact to determine palatability. Decreases in plant palatability over time paralleled decreases in protein content. Ant size was the most important variable determining the rate at which ants cut leaves. Trichome characteristics were uncorrelated with the rate at which leaves were cut, while leaf toughness explained a small amount of the variance in cutting rate.

The results suggest that leaf toughness and trichome characteristics within the ranges encountered by leafcutting ants in this tropical deciduous forest do not generally deter attack by ants. Instead, the results are consistent with the idea that leafcutting ants use a combination of plant secondary chemistry and nutrient availability to evaluate the quality of leaves.

Key words: antiherbivore defenses; Atta cephalotes; Costa Rica; herbivory; leaf nutrient content; leaf palatability; nonpolar extracts; plant secondary chemistry; toughness; trichomes; tropical deciduous forest.
\end{abstract}

\section{INTRODUCTION}

Physical features of plants, such as trichomes and the toughness of leaves, often protect plants from herbivory by insects. Trichomes may prevent or reduce feeding on plant tissues by mechanical means (Schillinger and Gallun 1968, Singh et al. 1971), impale and kill insects (Pillemer and Tingey 1978), and secrete toxic or immobilizing chemicals (Levin 1973, Tingey and Laubengayer 1981). The greater toughness of mature leaves than young leaves on a given plant results from increased concentrations of lignin and structural carbohydrates in mature leaves (Esau 1977). Highly lignified and fibrous plant tissues are difficult for many insects to ingest, and reduced feeding rates coupled with the poor nutritional quality of the material ingested can reduce growth rate and survivorship of insects (Feeny 1970, 1976). Reduced growth rates caused by trichomes and tissue toughness can also affect the

\footnotetext{
1 Manuscript received 2 October 1986; revised 23 May 1987; accepted 27 May 1987.
}

success of insect herbivores by prolonging life stages vulnerable to desiccation, parasitism, and predation (Feeny 1976, Moran and Hamilton 1980).

Leafcutting ants (Hymenoptera: Formicidae: Attini) are common generalist herbivores of the Neotropics that harvest large amounts of leaf tissue from a variety of woody plant species (Lugo et al. 1973, Haines 1978). Adult ants subsist primarily on plant juices imbibed from cut and crushed leaf tissues, and use solid leaf material to culture a mutualistic fungus that provides digestive enzymes to adults and is the only food of larvae (Quinlan and Cherrett 1979). Leafcutters exhibit striking patterns of preference for plants and plant tissues (Cherrett 1968, Rockwood 1975, 1976), and physical characteristics of leaves are thought to influence these patterns. The preference of leafcutting ants for young leaves has often been attributed to the greater toughness of mature leaves (Fennah 1950, Cherrett 1972). Cherrett (1972) found that workers of the leafcutting ant Atta cephalotes harvested pieces of leaves that were less tough than expected, compared with a 
random sample of available leaves. Waller $(1982 a, b)$ found that mature leaves of Berberis trifoliata (Berberidaceae) and Quercus fusiformis (Fagaceae) were palatable to the leafcutting ant Atta texana, but were too tough to cut. Finally, Wilson (1980) found that the size distribution of foraging workers in a laboratory colony of Atta sexdens was close to the theoretical size distribution that produced the maximum energy efficiency of harvest when cutting tough leaves.

Although plant species, individuals, and developmental stages differ in toughness, they may also differ in secondary chemistry or nutritional quality. Because chemical and physical factors may covary from plant to plant, or over time, it is often difficult to assess the role of physical characteristics in host-plant selection. Leafcutting ants respond to differences in chemistry between young and mature leaves as well as to differences in toughness (Cherrett and Seaforth 1970, Barrer and Cherrett 1972). Recent studies have established that leafcutters are highly sensitive to nonpolar plant secondary compounds (Littledyke and Cherrett 1978, Mudd et al. 1978, Hubbell et al. 1984, Wiemer 1985, Howard 1987), but no study has attempted to compare the relative influence of physical and chemical characteristics of leaves on diet selection by leafcutters. Here I report the results of two experiments designed to evaluate the relative importance of tissue toughness, trichome length and density, secondary chemistry, nutrient availability, and water content in diet selection by Atta cephalotes. I measured the palatability of whole leaves from 49 species of woody plants to a colony of Atta cephalotes and studied the relationship between palatability and physical and chemical leaf characteristics. I also measured the rate at which ants cut leaves and determined the relationship between cutting rate and ant size, leaf toughness, and leaf trichome characteristics.

\section{MATERIALS AND MethodS}

Field experiments on palatability were carried out in the early wet season of 1983, in Santa Rosa National Park, Costa Rica. The study site has been described in detail elsewhere (Howard 1987). Leaf harvesting activity by leafcutting ants at Santa Rosa reaches a yearly peak during the early wet season (Hubbell et al. 1984), and the relative palatability of plants is constant during this period of time (Howard 1987). I offered whole leaves from single individuals of 49 species of tropical woody plants to a leafcutting ant colony near park headquarters to determine their relative palatability at $10 \mathrm{~d}, 5 \mathrm{wk}$, and $10 \mathrm{wk}$ after the onset of the rains, during the 2nd wk of June, July, and August. Leaves were collected from each plant during each experimental period for analysis of chemical and physical characteristics. In a separate set of experiments in midJuly, $6 \mathrm{wk}$ after the onset of the rains, I measured the rates at which leaves that differed in toughness and trichome characteristics were cut by foraging ants.
Leaves were collected from plants growing in a 20ha patch of forest near park headquarters. The 49 plants studied were the same individuals previously studied (Howard 1987), minus the individual of Jacquinia pungens. This species sheds its leaves during the wet season, and the leaves of this plant were senescent prior to the first experiment. These plants represent about half of the common woody plant species in the forest patch, and were originally chosen without bias with respect to their palatability to leafcutting ants.

Leaves were collected from a single, marked branch on each plant throughout the entire study. Although repeated collections from a single branch might induce chemical defenses, no effect of prior sampling on palatability was discovered in experiments involving 20 of the 49 trees (Howard 1987). I collected leaves for palatability measurements by breaking off terminal branchlets of small leaves, or by snapping off the petioles of large leaves where they joined the stem. Sun leaves were collected whenever possible. Most leaves were removed from branchlets while submerged in a bucket of water, and petioles were inserted into small vials of water stoppered with cotton wads. This procedure was not possible with large leaves, but they were also inserted into vials of water to standardize the conditions under which ants encountered leaves. Leaves maintained their attractiveness for $\approx 4 \mathrm{~h}$ after collection, at which point changes in palatability became detectable. In all cases, experiments were initiated within $1 \mathrm{~h}$ of the time of collection and were completed within $3 \mathrm{~h}$ of collection.

I measured the palatability of leaves by placing a single detached leaf of each plant at the edge of an actively foraging trail of leafcutting ants and counting the number of pieces cut during two 1-h periods. Fresh leaves were used for each hour-long experiment, and the order of leaves along the trail during each hour was determined using a random number table. Leaves that were cut heavily during an experiment were replaced with new leaves to maintain constant availability of all leaf types. If ants were actively cutting leaves at the end of an experimental period, these leaves were removed from the trail, and ants were allowed to finish cuts already started. After each hour the activity of ants on the trail was measured by counting the number of ants passing a fixed point during three 1 -min periods. Experiments were conducted $\approx 30 \mathrm{~m}$ from the entrance to the colony to reduce the likelihood that individual ants would visit the experiment more than once per hour.

Because of the large number of plants in the study, all leaves could not be presented simultaneously to the ants. Each of the two observers could follow cutting activity on 10-15 leaves at a time, so the leaves were split into two groups and were presented to the ants on consecutive mornings. Plants were randomly assigned to the two groups and were randomly reassigned for each monthly block of experiments. To control for 
differences in ant activity between the days of presentation, I counted the number of oat flakes soaked in a $10 \%$ sucrose solution picked up by the ants during the last $15 \mathrm{~min}$ of each hour.

\section{Analysis of chemical and physical characteristics}

Quantitative analyses of leaf nutrients and water content, and qualitative analyses for the presence or absence of six classes of secondary chemicals, were performed on leaves collected from marked branches and have been previously reported in detail (Howard 1987). Leaves for chemical analyses and trichome measurements were collected no more than $1 \mathrm{wk}$ prior to whole-leaf bioassays, and at the same time of day as those collected for bioassays. Leaves for chemical analysis were air- and oven-dried $\left(40^{\circ} \mathrm{C}\right)$, crushed, and returned to the laboratory for analysis. Leaves collected for trichome measurements were numbered for identification and dried flat in a plant press. Leaves used in toughness determinations were collected on the same day as those presented to the ants in bioassays, and toughness was determined within $30 \mathrm{~min}$ of collection.

Trichome density and length were determined on five leaves from each sample. Leaves were examined under a dissecting microscope, and the number of trichomes in $1 \mathrm{~mm}^{2}$ of leaf lamina were estimated using an ocular micrometer with a square grid. Five areas were counted on the upper and five on the lower surface of each leaf and were evenly spaced from leaf base to tip. Accurate counts of trichome density were difficult to obtain in areas bisected by the midrib or large veins, and I avoided these areas. The length of five trichomes on each surface of each leaf was measured with an ocular micrometer with a linear scale. I measured trichomes that were parallel to the leaf surface, or nearly so, whenever possible. On some leaves the trichomes were nearly always erect, and I measured only trichomes that were at an approximate angle of $30^{\circ}$ or $45^{\circ}$ to the leaf surface. Trichomes were selected for measurement by haphazardly positioning the leaf on the microscope stage and rotating the ocular until one or more acceptable trichomes were aligned with the linear scale. The true length of trichomes that were at an angle to the leaf surface was calculated by dividing the apparent length by the cosine of the angle.

The toughness of leaves from each plant was determined in the field within $30 \mathrm{~min}$ of collection. I used a commercial penetrometer (Chatillion Company, model 509-1000) with a homemade tip of hard rubber (20 $\mathrm{mm}^{2}$ in area) to determine the pressure required to penetrate the leaf lamina. I placed each leaf between two sheets of plexiglass that had several drilled holes to accommodate the penetrometer tip, and held the leaf in place by tightening four screws at the corners of the assembly. The penetrometer tip was then pressed against the leaf lamina until it broke through, and the mass required to produce the breakthrough pressure was recorded from the indicator on the penetrometer. This mass value (in grams) was then converted to a pressure in kilopascals. I avoided the midrib in positioning leaves for penetrometer measurements because leafcutting ants frequently avoided cutting the midribs of leaves. I took a total of 20 measurements from four to six leaves in each sample, depending on leaf size.

\section{Measurements of cutting rate}

The rate at which foraging ants cut leaves was measured $6 \mathrm{wk}$ after the onset of the rains, in a set of experiments separate from those on leaf palatability. Leaves of 15 species that varied in toughness and trichome density were presented to ants on the same trail used for palatability measurements. I selected species that represented low, middle, and high ranges of the toughness distribution during July to ensure that the range of toughness encountered by ants was approximately equal in cutting and palatability measurements. I used a hand lens to select species that had sparse, moderate, and dense trichome cover. It was not possible to measure trichome length accurately in the field, and I made no attempt to match the range of trichome lengths in the two groups of plants. Leaves were again presented to ants in vials of water, and ants were timed from the beginning to the end of cuts. After a single cut was completed, the leaf was removed from the trail and the ant was collected. The length of the arc cut by each ant was measured, and the cutting rate was calculated as millimetres per minute. The toughness of each leaf was measured as described previously, and the mean of five measurements was taken as the average toughness for the leaf. Ant head widths were measured to the nearest $0.1 \mathrm{~mm}$ using a vernier caliper.

\section{Statistical analysis}

The data were analyzed using the SAS statistical package at the University of Iowa computing center. An analysis of covariance was used to determine the relationship of plant chemistry and physical characteristics to palatability. Information on secondary chemistry and nutrient and moisture availability in leaves was taken from Howard (1987). Information on secondary chemistry was reported as the presence or absence in plant samples of hydrolyzable tannins, condensed tannins, alkaloids, and nonpolar compounds of varying deterrency. This presence/absence data, and the month during which palatability measurements were made, were treated as class variables in the analysis. Quantitative measurements of total nitrogen, protein nitrogen, nonstructural carbohydrates, harvestable biomass (mass per square millimetre of leaf surface area), and moisture availability were also obtained from Howard (1987). These variables, and the measurements of toughness and trichome length and density, were treated as covariates in the analysis. The number of oat flakes picked up by ants at the end of each hour was also included in the analysis as a covariate, to 
TABLE 1. Patterns of leaf cutting and foraging activity by ants in hour-long experiments during three experimental periods. Ant activity and oat flakes harvested are $\bar{X} \pm 1 \mathrm{SD}$. Row entries followed by different superscript letters are significantly different $(P<.05$, Tukey's HSD test $)$.

\begin{tabular}{lccc}
\hline \hline & \multicolumn{3}{c}{ Experimental period } \\
\cline { 2 - 4 } & June & July & August \\
\hline Total leaf pieces harvested & 356 & 52 & 4 \\
Ants passing bioassay site per minute* & $175.8 \pm 102.0^{\mathrm{a}}$ & $291.8 \pm 107.0^{\mathrm{b}}$ & $124.4 \pm 44.2^{\mathrm{a}}$ \\
Oat flakes harvested in 15 min $\dagger$ & $22.5 \pm 2.6^{\mathrm{a}}$ & $32.0 \pm 7.7^{\mathrm{a}}$ & $28.8 \pm 2.5^{\mathrm{a}}$ \\
\hline
\end{tabular}

$* N=12$.

$\dagger N=4$.

control for differences in ant numbers during different experiments. I examined the residuals from the analysis and found that a $\log$ transformation of the dependent variable [(leaf pieces cut per hour) +1 ] yielded a satisfactory approximation to the normal distribution.

Because the continuous independent variables were intercorrelated to some extent, I examined variance inflation factors to determine whether the effect of each variable could be estimated independently of all others (SAS 1982). A variance inflation factor of 10.0 is considered evidence of an unacceptable degree of colinearity among variables (SAS 1982). Variance inflation factors were $<4.0$ in all cases, indicating that the independent variables were sufficiently independent of one another to obtain reliable estimates of regression parameters from an analysis of covariance.

I used the analysis of covariance to test for the significance of main effects of leaf characteristics on palatability, and of one-way interaction between leaf characteristics and the month of the experiment. The interaction terms provide information on the consistency of the effect of leaf characteristics on palatability over the course of the study period. Further analyses of the relationship between palatability and quantitatively varying plant traits used stepwise multiple regression (SAS 1982). In these analyses I forced the stepwise model to include the number of oat flakes harvested, to control for variation in ant numbers during tests. The influence of leaf toughness, trichome density, and ant size on cutting rate was also analyzed using stepwise multiple regression. In all stepwise analyses I ran forward-selection regression procedures using $P<$ .15 as the criterion for the entry and retention of variables in the regression model.

\section{RESULTS}

The number of leaf pieces cut by the ant colony in palatability trials decreased from 356 in June to 52 in July and only 4 in August (Table 1). The number of leaf pieces that were cut decreased despite greater numbers of ants on trails in July than in June and similar levels of ant activity during June and August (Table 1). In the June and July experiments most leaf pieces were cut from only a few plants, notably Spondias mombin, S. purpurea (Anacardiaceae) and Sapium thelocarpum (Euphorbiaceae). During the three experimental periods ants harvested a total of $>10$ leaf pieces from only 10 plants, which accounted for $78.2 \%$ of all leaf pieces cut during palatability measurements (Table 2).

During June and July large numbers of ants briefly left the trail in the area of the experiment, antennating or biting one or more leaves before returning to the trail or initiating cuts. Every leaf was investigated by at least one ant during the $1 \mathrm{st} 15 \mathrm{~min}$ of the experiment in both June and July, and many ants were recruited to favored leaves during the $1 \mathrm{st} 1 / 2 \mathrm{~h}$. The reduced number of leaf pieces cut in July reflects real differences in the number of cuts initiated by comparable numbers of ants. In contrast, the August experiments were marked by several consecutive mornings of overcast and light rain showers, and ants were much less inclined to leave the trail under these conditions. As a result, some leaves were never investigated by any ant during the entire $2 \mathrm{~h}$ they were offered. Ants did continue to investigate and accept oat flakes, which were placed in the trail itself (Table 1). The very low number of leaf sections cut in August may thus be due in part to decreased search effort by the ants off the trail, despite similar numbers of oat flakes harvested during all experimental periods.

Summary statistics on toughness and trichomes of the 49 plants revealed changes over time in some but not all characteristics (Table 3). The average toughness of leaves available to ants at Santa Rosa National Park was relatively low in June, when many new leaves are available, and significantly higher in July and August. In contrast, trichome densities on both top and bottom leaf surfaces were higher in June than in July or August. Trichome length did not vary over time. Overall, young leaves available to foraging ants are less tough and richer in nutrients and moisture (Howard 1987), but are hairier than mature leaves.

\section{Relationship between leaf characteristics and palatability}

Only the data from the June and July palatability experiments were used in the analysis of covariance because very few ants investigated leaves during the August experiments. The decrease in the number of leaf disks harvested from June to August may be cor- 
TABLE 2. Plants from which a total of 10 or more leaf pieces were cut during June, July, and August palatability trials. Plant names follow Janzen and Liesner (1980) except as noted.

\begin{tabular}{llcr}
\hline \hline \multicolumn{1}{c}{ Species } & \multicolumn{1}{c}{ Family } & $\begin{array}{c}\text { Total no. of leaf } \\
\text { pieces cut }\end{array}$ & $\begin{array}{c}\text { Percent of all } \\
\text { pieces cut }\end{array}$ \\
\hline Spondias mombin & Anacardiaceae & 59 & 14.3 \\
Sapium thelocarpum & Euphorbiaceae & 56 & 13.6 \\
Spondias purpurea & Anacardiaceae & 55 & 13.4 \\
Bursera simaruba & Burseraceae & 32 & 7.8 \\
Bombacopsis quinatum & Bombacaceae & 28 & 6.8 \\
Calycophyllum candidissimum & Rubiaceae & 26 & 6.3 \\
Chlorophora tinctoria & Moraceae & 22 & 5.3 \\
Trichilia martiana* & Meliaceae & 16 & 3.9 \\
Genipa americana & Rubiaceae & 14 & 3.4 \\
Zanthoxylum setulosum & Rutaceae & 14 & 3.4 \\
All species & & 322 & 78.2 \\
\end{tabular}

* Determined by R. Liesner; synonymous with T. cuneata in Janzen and Liesner (1980).

related with changes in leaf characteristics, but it is not possible to estimate the variance due to leaf characteristics independent of the variance due to searching effort.

The analysis of covariance model, containing all main effects and interactions of leaf characteristics with month, accounted for $72.7 \%$ of the variance in number of leaf pieces cut in June and July (Table 4). Because of the large number of effects tested in the model (30), acceptance of significance levels between .05 and .01 may lead to an inflated overall probability of Type 1 error (Neter et al. 1985). Effects that are significant at this level must be interpreted with caution and should be considered to be only marginally significant.

Significance tests for individual effects in the model showed that leaf chemistry was strongly correlated with the number of leaf pieces cut from leaves (Table 4). The deterrency of nonpolar extracts and the presence of hydrolyzable tannins in plant samples were highly correlated with palatability (number of leaf disks cut; $P<.0001$ ). Leaves from plants that lacked deterrent nonpolar extracts (class 0 ) were highly palatable, while those from plants with slightly or significantly deterrent nonpolar extracts (classes 1-3) were relatively unpalatable (Fig. 1). In contrast, leaf samples that contained hydrolyzable tannins were significantly more palatable than samples that lacked hydrolyzable tannins (Fig. 1). The harvestable biomass of leaves (dry mass per unit area) and trichome length on the upper leaf surface were also marginally correlated with palatability $(P<$ .05). However, regressions of each variable on palatability showed that neither explained a large amount of the variance ( $r^{2} \approx 0.01$ in each case), reinforcing the view that they are not strongly related to palatability. No significant relationship of palatability to water content, toughness, or other indices of trichome characteristics or nutritional quality was found.

I investigated the possibility that separate measurements of the four trichome characteristics might have underestimated their importance by subdividing the sums of squares among four effects. I reran the analysis of covariance using an alternative formulation of trichome characteristics, the first principal component of the four measurements (accounting for $49 \%$ of the total variance in trichome length and density). I also ran the analysis using a "hairiness" index constructed by summing the total trichome lengths (density $\times$ length) in a square millimetre of the top and bottom surfaces of each leaf. In both cases the variance explained by the model decreased to $\approx 68 \%$, and neither alternative formulation of trichome characteristics was found to be significant.

TABLE 3. Variation in leaf toughness and trichome length and density in 49 tropical woody plant species during three experimental periods $(\bar{X} \pm 1 \mathrm{SD})$. Row entries followed by different superscript letters are significantly different $(P<.05$, Tukey's HSD test).

\begin{tabular}{|c|c|c|c|}
\hline & \multicolumn{3}{|c|}{ Experimental period } \\
\hline & June & July & August \\
\hline Toughness ( $\mathrm{kPa}$ to penetrate) & $110 \pm 12.8^{\mathrm{a}}$ & $159 \pm 10.5^{b}$ & $167 \pm 10.0^{\mathrm{b}}$ \\
\hline \multicolumn{4}{|l|}{ Trichome density (no. $/ \mathrm{mm}^{2}$ ) } \\
\hline $\begin{array}{l}\text { Top } \\
\text { Bottom }\end{array}$ & $\begin{array}{l}12.78 \pm 2.94^{\mathrm{a}} \\
37.24 \pm 7.13^{\mathrm{a}}\end{array}$ & $\begin{aligned} 6.87 & \pm 1.69^{\mathrm{b}} \\
23.30 & \pm 5.22^{\mathrm{b}}\end{aligned}$ & $\begin{aligned} 6.22 & \pm 1.62^{\mathrm{b}} \\
22.87 & \pm 5.98^{\mathrm{b}}\end{aligned}$ \\
\hline \multicolumn{4}{|l|}{ Trichome length (mm) } \\
\hline $\begin{array}{l}\text { Top } \\
\text { Bottom }\end{array}$ & $\begin{array}{l}0.23 \pm 0.03^{\mathrm{a}} \\
0.26 \pm 0.03^{\mathrm{a}}\end{array}$ & $\begin{array}{l}0.19 \pm 0.03^{\mathrm{a}} \\
0.23 \pm 0.10^{\mathrm{a}}\end{array}$ & $\begin{array}{l}0.22 \pm 0.03^{\mathrm{a}} \\
0.28 \pm 0.03^{\mathrm{a}}\end{array}$ \\
\hline
\end{tabular}


TABle 4. Analysis of covariance of the effect of chemical and physical characteristics on the palatability of whole leaves (number of pieces cut in $1 \mathrm{~h}$ ).

\begin{tabular}{|c|c|c|c|c|c|}
\hline Source & $\mathrm{df}$ & $\begin{array}{l}\text { Type IV sum } \\
\text { of squares }\end{array}$ & $\begin{array}{c}\text { Mean } \\
\text { square }\end{array}$ & $F$ & $P$ \\
\hline $\begin{array}{l}\text { Model } \\
\text { Error } \\
\text { Total }\end{array}$ & $\begin{array}{r}36 \\
155 \\
191\end{array}$ & $\begin{array}{r}20.22 \\
7.61 \\
27.83\end{array}$ & $\begin{array}{l}0.56 \\
0.05\end{array}$ & 11.44 & $<.0001$ \\
\hline $\begin{array}{l}\text { Blocking variable } \\
\text { Month* }\end{array}$ & 1 & 0.01 & 0.01 & 0.07 & .7940 \\
\hline $\begin{array}{l}\text { Covariate controlling for number of ants } \\
\text { No. oat flakes taken }\end{array}$ & 1 & 0.01 & 0.01 & 0.19 & .6727 \\
\hline $\begin{array}{l}\text { Main effects of leaf chemistry } \\
\text { Nonpolar deterrency } \\
\text { Alkaloids } \\
\text { Hydrolyzable tannins } \\
\text { Condensed tannins } \\
\text { Protein } \\
\text { Nitrogen } \\
\text { Nonstructural carbohydrate } \\
\text { Harvestable biomass } \\
\text { Water }\end{array}$ & $\begin{array}{l}3 \\
2 \\
1 \\
1 \\
1 \\
1 \\
1 \\
1 \\
1\end{array}$ & $\begin{array}{l}2.77 \\
0.27 \\
0.87 \\
0.13 \\
0.01 \\
0.02 \\
0.08 \\
0.29 \\
0.01\end{array}$ & $\begin{array}{l}0.92 \\
0.13 \\
0.87 \\
0.13 \\
0.01 \\
0.02 \\
0.08 \\
0.29 \\
0.01\end{array}$ & $\begin{array}{r}18.82 \\
2.74 \\
17.64 \\
2.67 \\
0.21 \\
0.33 \\
1.56 \\
5.87 \\
0.01\end{array}$ & $\begin{array}{r}<.0001 \\
.0678 \\
<.0001 \\
.1041 \\
.6504 \\
.5677 \\
.2138 \\
.0166 \\
.9434\end{array}$ \\
\hline $\begin{array}{l}\text { Main effects of toughness and trichomes } \\
\text { Toughness }\end{array}$ & 1 & 0.01 & 0.01 & 0.19 & .6653 \\
\hline $\begin{array}{l}\text { Density } \\
\text { Top } \\
\text { Bottom }\end{array}$ & $\begin{array}{l}1 \\
1\end{array}$ & $\begin{array}{l}0.07 \\
0.01\end{array}$ & $\begin{array}{l}0.07 \\
0.01\end{array}$ & $\begin{array}{l}1.40 \\
0.08\end{array}$ & $\begin{array}{l}.2387 \\
.7789\end{array}$ \\
\hline $\begin{array}{l}\text { Length } \\
\text { Top } \\
\text { Bottom }\end{array}$ & $\begin{array}{l}1 \\
1\end{array}$ & $\begin{array}{l}0.28 \\
0.07\end{array}$ & $\begin{array}{l}0.28 \\
0.07\end{array}$ & $\begin{array}{l}5.63 \\
1.44\end{array}$ & $\begin{array}{l}.0189 \\
.2326\end{array}$ \\
\hline $\begin{array}{l}\text { Interactions of chemistry with month } \\
\text { Month } \times \text { nonpolar } \\
\text { Month } \times \text { alkaloids } \\
\text { Month } \times \text { hydrolyzable tannins } \\
\text { Month } \times \text { condensed tannins } \\
\text { Month } \times \text { protein } \\
\text { Month } \times \text { nitrogen } \\
\text { Month } \times \text { nonstructural carbohydrate } \\
\text { Month } \times \text { biomass } \\
\text { Month } \times \text { water } \\
\text { Month } \times \text { toughness }\end{array}$ & $\begin{array}{l}3 \\
2 \\
1 \\
1 \\
1 \\
1 \\
1 \\
1 \\
1 \\
1\end{array}$ & $\begin{array}{l}0.72 \\
0.36 \\
0.04 \\
0.13 \\
0.03 \\
0.31 \\
0.34 \\
0.16 \\
0.00 \\
0.03\end{array}$ & $\begin{array}{l}0.24 \\
0.18 \\
0.04 \\
0.13 \\
0.03 \\
0.31 \\
0.34 \\
0.16 \\
0.00 \\
0.03\end{array}$ & $\begin{array}{l}4.89 \\
3.63 \\
0.72 \\
2.61 \\
0.69 \\
6.41 \\
6.84 \\
3.35 \\
0.00 \\
0.64\end{array}$ & $\begin{array}{c}<.005 \\
.0287 \\
.3991 \\
.1080 \\
.4086 \\
.0124 \\
<.01 \\
.0691 \\
.9788 \\
.4260\end{array}$ \\
\hline $\begin{array}{l}\text { Month } \times \text { density } \\
\text { Top } \\
\text { Bottom }\end{array}$ & $\begin{array}{l}1 \\
1\end{array}$ & $\begin{array}{l}0.01 \\
0.00\end{array}$ & $\begin{array}{l}0.01 \\
0.00\end{array}$ & $\begin{array}{l}0.13 \\
0.00\end{array}$ & $\begin{array}{l}.7141 \\
.9453\end{array}$ \\
\hline $\begin{array}{l}\text { Month } \times \text { length } \\
\text { Top } \\
\text { Bottom }\end{array}$ & $\begin{array}{l}1 \\
1\end{array}$ & $\begin{array}{l}0.28 \\
0.27\end{array}$ & $\begin{array}{l}0.28 \\
0.27\end{array}$ & $\begin{array}{l}5.61 \\
5.57\end{array}$ & $\begin{array}{l}.0191 \\
.0195\end{array}$ \\
\hline
\end{tabular}

* Only data from June and July were used because very few ants investigated leaves in August.

Several interactions of plant characteristics with the month of the experiment were found to be significant, but only those involving nonstructural carbohydrate content and deterrency of nonpolar extracts were more than marginally so (Table 4). The interaction between nonstructural carbohydrate content and the month of the experiment was investigated by running separate regressions of palatability on carbohydrate content for each month. These regressions showed that palatability was essentially uncorrelated with carbohydrate content during the month of June $\left(r^{2}=0.0004, \mathrm{NS}\right)$ and was slightly correlated during July $\left(r^{2}=0.026, .10<P<\right.$ $.05)$.
The interaction between deterrency of nonpolar extracts and the month of the experiment means that the slope of the relationship between palatability and deterrency of nonpolar extracts differs between the two months considered (Fig. 2). One-way analyses of variance for each month revealed that the mean palatability of plants lacking deterrent extracts (class 0 ) was significantly greater than the palatability of those with slightly (class 1) or significantly deterrent extracts (classes $2-3)$ in June but not in July $(P<.05$, Tukey's HSD test). All plants were more palatable in June than in July, but this difference was significant only for plants lacking deterrent nonpolar extracts $(P<.05$, Tukey's 

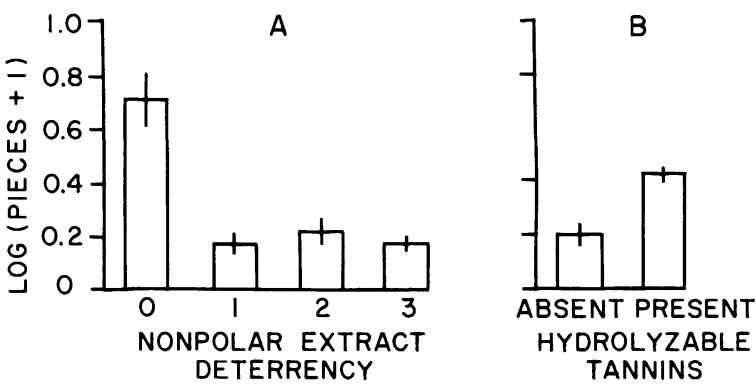

FIG. 1. Relationship of plant secondary chemicals to number of pieces cut from leaves by leafcutting ants in 1-h field experiments. Narrow vertical bars show \pm 1 standard error. Data on secondary chemistry are from Howard (1987). (A) Deterrency of nonpolar extracts, determined by laboratory bioassays. 0 : extract not deterrent; 1 : extract slightly but not significantly deterrent; 2 : extract significantly deterrent $(P<$ $.05)$; 3: extract highly deterrent $(P<.001)$. See Howard (1987) for details of the bioassays. (B) Presence or absence of hydrolyzable tannins, determined by spot tests.

HSD test). Plants with deterrent nonpolar extracts were thus consistently unpalatable, while those lacking deterrent extracts decreased in palatability from June to July.

Were month-to-month changes in palatability of plants that lacked deterrent nonpolar extracts related to changes in other leaf characteristics? Stepwise multiple regression of nutrients, moisture, toughness, and trichome characteristics on the palatability of these plants revealed that protein content was positively correlated with palatability $(P<.025$, Fig. 3$)$. Mean protein content of the eight plants that lacked deterrent nonpolar extracts dropped from $3.38 \%$ in June to $2.89 \%$ in July, paralleling the decrease in palatability of these plants.

\section{Measurements of cutting rates}

I obtained 119 observations of cutting rate for foraging ants of different sizes. The toughness range of leaves actually used in cutting-rate measurements (133$422 \mathrm{kPa}$ ) was somewhat higher than that of leaves offered in palatability tests $(35-346 \mathrm{kPa})$, but the range of top and bottom trichome densities in the two tests was virtually identical. Trichome lengths of leaves offered in cutting-rate determinations (top: $0-0.37 \mathrm{~mm}$, bottom: $0-0.48 \mathrm{~mm}$ ) covered only the lower half of the entire range of lengths found in all 49 plants (top: 0$0.78 \mathrm{~mm}$, bottom: $0-0.99 \mathrm{~mm}$ ), but very long trichomes were rare. Only eight plants had trichomes on the top leaf surface longer than the range offered in cutting-rate measurements, and only four had longer trichomes on the bottom leaf surface.

Ants cut one or more leaf pieces from each of the 15 different plants presented in cutting tests. Leaf pieces were cut from both hairy and glabrous leaves, and no noticeable bias against hairy leaves was observed in ants that investigated the leaves. The stepwise regres- sion indicated that ant size had the single greatest effect on cutting rate $\left(r^{2}=0.35, P<.0001\right)$ and that leaf toughness also explained a small amount of the variance in cutting rate $\left(r^{2}=0.05, P<.05\right.$; Fig. 4$)$. Trichome length and density were found to have no effect on cutting rate. I reran the stepwise model, substituting the first principal component of trichome length and density, and the hairiness index previously described, but in neither case did trichome characteristics enter the model.

\section{DisCUSSION}

Previous studies of leafcutting ants have found correlations between the palatability of plants or the probability of ant attack and leaf toughness (Cherrett 1972, Waller 1982a,b), water content (Cherrett 1972, Bowers and Porter 1981), and secondary chemistry (Waller 1982b, Hubbell et al. 1984). In general, these studies focussed on one or a small number of leaf characteristics and did not attempt to estimate the importance of any characteristic independent of all others. By simultaneously evaluating a large number of relevant leaf characteristics, this study provides information on the relative influence of each characteristic on the palatability of plants to leafcutting ants. Such insights are particularly valuable for understanding the diet selection of a genereralist herbivore such as leafcutting ants, whose choices may be influenced to some extent by many plant characteristics.

The use of a single individual from many different plant species ensured that ants were presented with a wide range of plant characteristics and combinations of characteristics representative of those found in the plant community. This approach is useful for identifying plant characteristics influential in diet selection

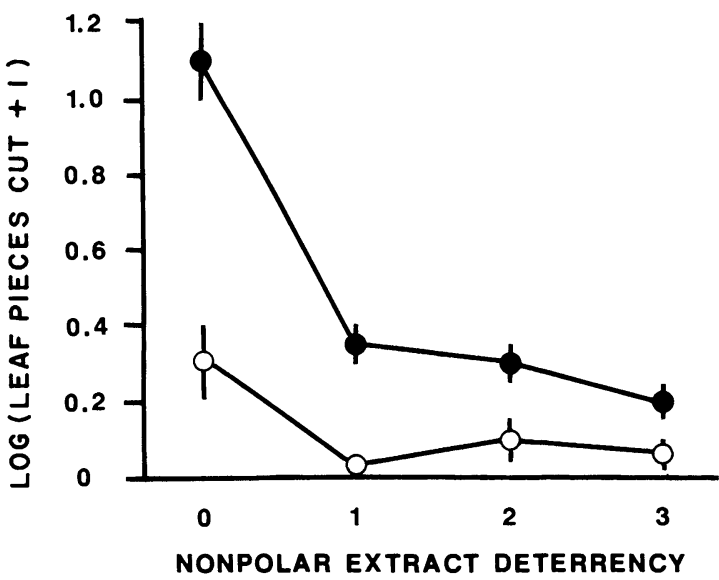

FIG. 2. Relationship of palatability and the deterrency of plant nonpolar extracts, during 1-h June (O) and July (O) palatability tests. Vertical bars show \pm 1 standard error. 0 : extract not deterrent; 1 : extract slightly but not significantly deterrent; 2 : extract significantly deterrent $(P<.05)$; 3: extract highly deterrent $(P<.001)$. 


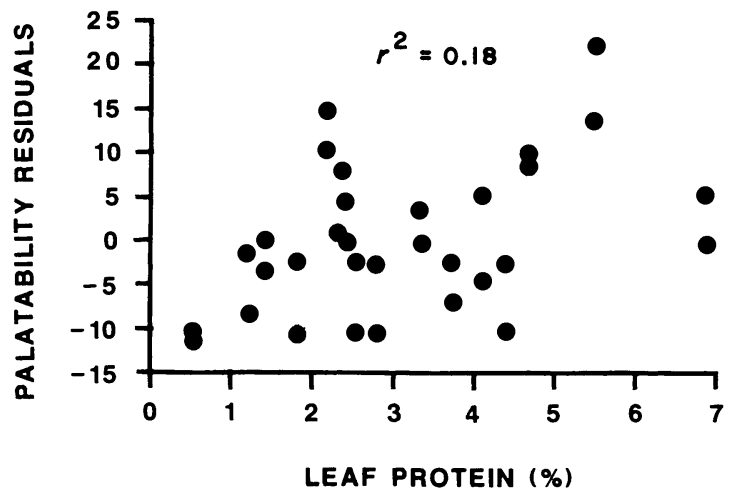

FIG. 3. Partial regression plot of palatability vs. leaf protein content, controlling for ant activity (number of oat flakes harvested), for plants containing nondeterrent nonpolar extracts. $r^{2}$ value is from stepwise multiple regression.

by a generalized herbivore but is inappropriate for making inferences about the reasons for the vulnerability or resistance of particular plant species to leafcutting ant attack. The single individual used in this study is unlikely to be representative of the species as a whole for all leaf characteristics. This study seeks to identify general rules of diet selection by leafcutting ants, but the factors in a given plant species that confer resistance or vulnerability to attack are best identified by detailed studies of each species.

\section{Secondary chemistry and palatability}

The results of this study suggest that secondary chemistry is the best predictor of leafcutting ant preferences for available plant species during the period of maximum leaf harvest in nature. Differences in the relative palatability of plants were strongly related to the deterrency of nonpolar extracts and the presence or absence of hydrolyzable tannins. Energy availability (harvestable biomass) and trichome characteristics were marginally related to palatability, while no relationship was found between palatability and leaf toughness or water content. Some interactions were found to be significant in the statistical analysis, suggesting that the relationship of leaf characteristics to palatability varies over time. The relative palatability of plant species clearly depends on a number of leaf characteristics, but patterns of secondary chemistry appear to be the most influential during the early wet season.

The deterrency of nonpolar extracts was negatively correlated with the palatability of plants and had the strongest influence on palatability of any plant characteristic measured (Table 4). In contrast, the presence of hydrolyzable tannins in extracts was associated with plants of high palatability. This pattern results because plants that contained deterrent nonpolar extracts rarely contained hydrolyzable tannins (Howard 1987). Because the deterrency of nonpolar extracts explains a much greater proportion of the variance than does the presence or absence of hydrolyzable tannins, it is likely that ants avoid plants that contain nonpolar deterrents rather than seek out those that contain hydrolyzable tannins.

These results are similar to those obtained in previous experiments on diet selection by Atta cephalotes at Santa Rosa National Park. Hubbell et al. (1984) found that the relative palatability of plants was closely related to patterns of plant secondary chemistry. Howard (1987) measured palatability using leaf disk bioassays and evaluated the relative impact on diet selection of water content and nutritional and secondary chemistry, and also found plant secondary chemistry to be most closely related to palatability. In both Howard (1987) and the present study the deterrency of nonpolar leaf extracts was negatively correlated, and the presence of hydrolyzable tannins positively correlated, with the palatability of leaves. The results of the two studies are qualitatively identical, although different techniques were used to assess palatability and different numbers of variables were measured.

\section{Toughness and trichome characteristics}

Neither the analysis of covariance nor the cuttingrate measurements support the idea that physical bar-
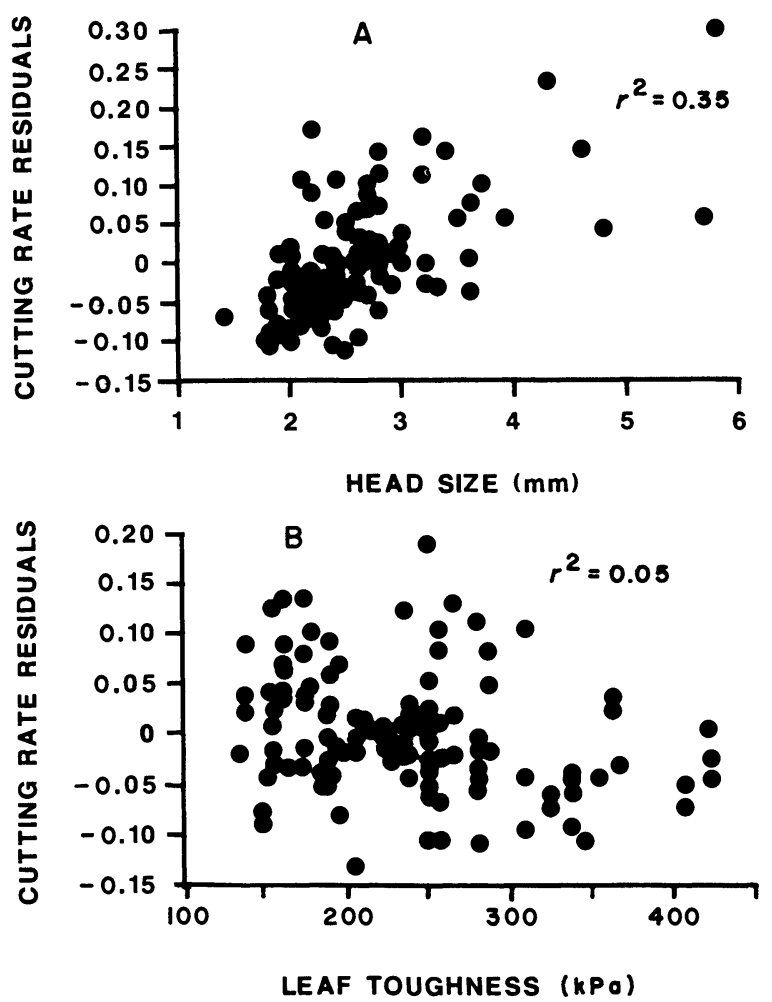

FIG. 4. Partial regression plots of leaf cutting rates on ant head size and leaf toughness. $r^{2}$ values are from stepwise multiple regression. (A) Plot of leaf-cutting rate against ant head size, controlling for leaf toughness. (B) Plot of leaf-cutting rate against leaf toughness, controlling for ant head size. 
riers to leaf cutting are of major importance to diet selection by leafcutting ants. Toughness and trichome characteristics varied widely from plant to plant and over time (Table 3), but systematic effects of these characters on palatability and cutting rate were small. Trichome length was marginally correlated with the total number of leaf disks cut per hour, but trichome length and density had no effect at all on the time required to complete a given cut. From these results it appears that trichomes may influence ant behavior primarily by influencing the decision to cut leaves, rather than inferfering with cutting itself. Trichomes might interfere with the ability of ants to gain information about leaves through antennation or initial biting and tasting of leaf juices prior to the initiation of cutting behavior.

There is also little evidence that leaf toughness within a wide range of values influences the ability of ants to cut leaves. Toughness was unrelated to palatability as measured by the number of leaf pieces cut per hour in whole-leaf bioassays. Although the toughness of leaves did reduce the speed of cutting, toughness had only a minor effect in comparison with ant size (Fig. 4). It has been suggested that the size distribution of leafcutting ant trail foragers has been optimized over evolutionary time for the efficient cutting of tough leaves (Wilson 1980). The evolution of caste ratios and body size in leafcutters in response to the challenges of leaf cutting may thus have reduced the importance of tissue toughness in diet selection at the present time. Despite the current lack of a pervasive influence of leaf toughness, in the past this may have been an extremely important selective pressure on leafcutters.

Although the results suggest that physical barriers to leaf cutting have little effect on ant preferences among many available plant species, this conclusion is valid only within the range of variation examined in this study. Very tough species at Santa Rosa National Park might well escape attack for this reason alone. Toughness could be a major constraint on diet selection in habitats in which the leaves of plants consistently exceed the range of toughness reported here. Such conditions might be expected in habitats typified by sclerophyllous vegetation such as the deserts and thorn forests of Mexico and the southwestern United States. Studies conducted in Texas have in fact reported that toughness is a major deterrent to attack by the leafcutting ant Atta texana (Waller 1982a, b). This result might be explained by exceptional toughness of the plants studied, but might equally well reflect general conditions prevailing in the plant community in this area.

\section{Leaf nutrient content and palatability}

No measure of nutrient content in leaves was as strongly related to palatability as secondary chemistry, but there is evidence that nutrient content is important to diet selection by leafcutting ants. Patterns of sec- ondary chemistry were strongly related to which plants were cut and which were avoided, but within the subset of highly palatable, frequently cut plants, protein content was significantly correlated with palatability. Secondary chemistry and nutritional quality may thus interact to determine palatability. The results suggest that plants are cut if their secondary chemistry can be tolerated by the ants and their fungus, but the amount cut depends on the quality of the leaves. This is consistent with observations that the preferences of Atta cephalotes for cultivated plants, which are presumably less well defended than wild plants, are correlated with nitrogen content (Berish 1986).

Nonstructural carbohydrate content was weakly correlated with palatability in July but not in June, suggesting that nutrient availability might play a greater role in diet selection later in the wet season. This is consistent with previous work on diet selection at Santa Rosa National Park, in which the relationship between nonstructural carbohydrate content and palatability of leaves became progressively stronger from June to August (Howard 1987). Since indices of nutritional quality in the 49 plants tested generally declined from June to August (Howard 1987), nutrient availability may become more important in determining the relative palatability of plants as the quality of leaves decreases.

During the study there was variation both in the number of leaf pieces cut from different plants at a given time (relative palatability) and in overall levels of leaf-cutting activity over time. Previous studies at this site have reported that leaf harvest declines after the early wet season peak (Hubbell et al. 1984, Howard 1987), but this is the first study to find evidence that seasonal decreases in leaf harvest may be related to nutrient availability in leaves. The number of leaf pieces cut from all plants decreased from June to July (Fig. 2), largely due to changes in the palatability of plants lacking deterrent nonpolar extracts. The palatability of these plants was correlated with protein content, and both the protein content and the numbers of leaf disks harvested declined from June to July. This does not conclusively demonstrate that variation in nutrient content causes the observed patterns, because these plants frequently contained hydrolyzable tannins (Howard 1987), and it is possible that variation in tannin concentration also contributed to the decline in palatability.

Nutrient availability may affect the preferences of leafcutting ants for leaves in a number of ways, but the exact relationship between palatability and different measures of nutritional quality is still unclear. Previous studies at this site have found little evidence that leaf nutrients influence diet selection (Hubbell and Wiemer 1983, Howard 1987), although this may be in part due to the conservative statistical analysis used by Howard (1987). Protein content, nonstructural carbohydrates, and harvestable biomass all bore at least a weak relationship to palatability in this study, and Berish (1986) 
found that ant preferences were related to total nitrogen content of leaves. However, quantitative variation in plant secondary chemistry may also explain plant-toplant and month-to-month variation in palatability of preferred plants, and further insights into the role of nutrients and secondary chemicals in leafcutting ant diet selection must await studies that quantify both factors. Leaf nutrient content appears to be particularly important in plants that lack deterrent nonpolar ex. tracts, and these plants generally contain hydrolyzable tannins (Howard 1987). I suggest that detailed studies of highly palatable, tannin- and phenolic-rich plants will be of particular value in determining the relative contribution of quantitative variation in nutrients anc secondary chemicals to the preferences of leafcutting ants.

\section{ACKNOWLEDGMENTS}

I wish to thank L. Rohwer for assistance in the field and S. Chouinard, R. Grant, W. Lindback, S. Meagher, R. Mihalik, N. Palumbo, C. Sagers, W. Sbiliris, and P. Taft for assistance in the laboratory. S. Faeth, R. Montgomery, M. Newlon, J. Poulton, and D. Wiemer provided advice on the chemical methods. R. Kelley and R. Lenth, of the University of Iowa Statistical Consulting Service, provided advice on the statistical methods. R. Liesner of the Missouri Botanical Garden identified the majority of the plants. D. Janzen provided additional plant identifications and essential advice on the conduct of the field study. L. Johnson, S. Hubbell, D. Wiemer, S. Hendrix, J. Cazin, M. Rausher, and two anonymous reviewers offered valuable comments on the manuscript. The Servicio de Parques Nacionales of Costa Rica granted permission to conduct the fieldwork at Santa Rosa National Park, and the Organization for Tropical Studies provided logistical support throughout the study. This work was supported by a Teaching-Research Fellowship from the University of Iowa, a Jesse Smith Noyes research initiation award from the Organization for Tropical Studies, and National Science Foundation grants DEB 80-10638 and BSR 83-07105 to D. F. Wiemer and S. P. Hubbell. This work was completed in partial fulfillment of the requirements for the Ph.D. degree in the Department of Biology, University of Iowa.

\section{Literature Cited}

Barrer, P. M., and J. M. Cherrett. 1972. Some factors influencing the site and pattern of leaf-cutting activity in the ant Atta cephalotes L. Journal of Entomology Series A 47: 15-27.

$\rightarrow$ Berish, C. W. 1986. Leaf-cutting ants (Atta cephalotes) select nitrogen-rich forage. American Midland Naturalist 115:268276.

$\rightarrow$ Bowers, M. A., and S. D. Porter. 1981. Effect of foraging distance on water content of substrates harvested by Atta columbica (Guerin). Ecology 62:273-275.

$\rightarrow$ Cherrett, J. M. 1968. The foraging behavior of Atta cephalotes L. (Hymenoptera: Formicidae). I. Foraging pattern and plant species attacked in tropical rain forest. Journal of Animal Ecology 37:387-403.

- 1972. Some factors involved in the selection of vegetable substrate by Atta cephalotes (L.) (Hymenoptera: Formicidae) in tropical rain forest. Journal of Animal Ecology 41:647-660.

Cherrett, J. M., and C. E. Seaforth. 1970. Phytochemical arrestants for the leaf-cutting ants, Atta cephalotes (L.) and Acromyrmex octospinosus (Reich) with some notes on the ants' response. Bulletin of Entomological Research 59:615625.
Esau, K. T. 1977. Anatomy of seed plants. Second edition. John Wiley and Sons, New York, New York, USA.

Feeny, P. 1970. Seasonal changes in oak leaf tannins and nutrients as a cause of spring feeding by winter moth caterpillars. Ecology 51:565-581.

- 1976. Plant apparency and chemical defense. Recent Advances in Phytochemistry 10:1-40.

Fennah, R. G. 1950. Parasol ants, their life history and methods for their control. Proceedings of the Agricultural Society of Trinidad 50:312-326.

$\rightarrow$ Haines, B. L. 1978. Element and energy flows through colonies of the leaf-cutting ant, Atta columbica, in Panama. Biotropica 10:270-277.

Howard, J. J. 1987. Leafcutting ant diet selection: the role of nutrients, water, and secondary chemistry. Ecology 68: 503-515.

Hubbell, S. P., J. J. Howard, and D. F. Wiemer. 1984. Chemical leaf repellency to an attine ant: seasonal distribution among potential host plant species. Ecology 65:10671076.

Hubbell, S. P., and D. F. Wiemer. 1983. Host plant selection by an attine ant. Pages 133-154 in P. Jaisson, editor. Social insects in the tropics. Volume 2. University of Paris Press, Paris, France.

Janzen, D. H., and R. Liesner. 1980. Annotated check-list of plants of lowland Guanacaste Province, Costa Rica, exclusive of grasses and non-vascular cryptogams. Brenesia 18:15-90.

Levin, D. A. 1973. The role of trichomes in plant defense. Quarterly Review of Biology 48:3-15.

Littledyke, M., and J. M. Cherrett. 1978. Defense mechanisms in young and old leaves against cutting by the leafcutting ants Atta cephalotes (L.) and Acromyrmex octospinosus (Reich) (Hymenoptera: Formicidae). Bulletin of Entomological Research 68:263-271.

Lugo, A. E., E. G. Farnsworth, D. G. Pool, P. Jerez, and G. Kaufman. 1973. The impact of the leaf-cutting ant Atta columbica on the energy flow of a tropical wet forest. Ecology 54:1292-1301.

Moran, N., and W. D. Hamilton. 1980. Low nutritive quality as defense against herbivores. Journal of Theoretical Biology 86:247-254.

Mudd, A., D. J. Peregrine, and J. M. Cherrett. 1978. The chemical basis for the use of citrus pulp as a fungus garden substrate by the leafcutting ants Atta cephalotes (L.) and Acromyrmex octospinosus (Reich) (Hymenoptera: Formicidae). Bulletin of Entomological Research 68:673-685.

Neter, J., W. Wasserman, and M. H. Kutner. 1985. Applied linear statistical models. Second edition. Irwin, Homewood, Illinois, USA.

Pillemer, E. A., and W. D. Tingey. 1978. Hooked trichomes and resistance of Phaseolus vulgaris to Empoasca fabae (Harris). Entomologia Experimentalis et Applicata 24:8394.

Quinlan, R. J., and J. M. Cherrett. 1979. The role of fungus in the diet of the leaf-cutting ant Atta cephalotes (L.). Ecological Entomology 4:151-160.

Rockwood, L. L. 1975. The effects of seasonality on foraging in two species of leaf-cutting ants $(\mathrm{Atta})$ in Guanacaste Province, Costa Rica. Biotropica 7:176-185.

- 1976. Plant selection and foraging patterns in two species of leaf-cutting ants (Atta). Ecology 57:48-61.

SAS. 1982. SAS user's guide: statistics. 1982 edition. SAS Institute, Cary, North Carolina, USA.

Schillinger, J. A., and R. L. Gallun. 1968. Leaf pubescence of wheat as a deterrent to the cereal leaf beetle, Oulema melamopus. Annals of the Entomological Society of America 61:900-903.

Singh, B. B., H. H. Hadley, and R. L. Bernard. 1971. Morphology of pubescence in soybeans and its relation to plant vigor. Crop Science 11:13-16. 
Tingey, W. M., and J. E. Laubengayer. 1981. Defense against the green peach aphid and potato leafhopper by glandular trichomes of Solanum berthaultii. Journal of Economic Entomology 74:721-725.

Waller, D. A. 1982a. Leaf-cutting ants and live oak: the role of leaf toughness in seasonal and intraspecific host choice Entomologia Experimentalis et Applicata 32:146-150.

. 1982b. Leaf-cutting ants and avoided plants: de- fenses against Atta texana attack. Oecologia (Berlin) 52: 400-403.

Wiemer, D. F. 1985. Natural repellents of the leaf cutter ants. Revista Latinoamericana de Quimica 16:98-102.

Wilson, E. O. 1980. Caste and division of labor in leafcutter ants (Hymenoptera: Formicidae: Atta). II. The ergonomic optimization of leaf cutting. Behavioral Ecology and Sociobiology 7:157-165. 